Paper presented at

Flemish Scientific Economic Conference 2010

Ghent University, Ghent, Belgium

November 19, 2010.

\title{
Politics and public infrastructure investments in local governments : empirical evidence from Flemish municipalities (1996-2006)
}

\section{Stijn Goeminne \& Carine Smolders ${ }^{1}$}

\author{
Faculty of Business Administration and Public Administration \\ University College Ghent \\ Voskenslaan 270, B-9000 Ghent, Belgium \\ Ghent University \\ e-mail: stijn.goeminne@hogent.be,carine.smolders@hogent.be
}

Key-words

public investment, public infrastructure, partisan politics, political fragmentation, yardstick competition, political budget cycles, Flemish municipalities.

\section{Abstract}

In this paper, we estimate a public infrastructure investment function using a panel data set of 307 Flemish municipalities for the period 1996-2006. We particularly draw attention to political determinants of public infrastructure investment decisions. We show that the characteristics of the government, such as partisan affiliation and fragmentation, affect the level of public infrastructure investments Local governments are also sensitive to the investment policy of neighbouring municipalities. There is a positive interaction effect that changes own investments by $20 \%$ of that of neighbouring municipalities. Finally, elections obviously have an impact on investment policy. Investments increase the nearer elections come, with highest investments in the year before elections.

1 Corresponding author: Stijn Goeminne, e-mail: stijn.goeminne@hogent.be, Tel: +32 9248 88 34, Fax: +32 9242 4209. 


\section{Introduction}

Public investments or public infrastructure can be the subjects of research from various perspectives such as their contribution to productivity/growth (e.g. Aschauer, 1989; Mizutani \& Tanaka, 2008 or Ratner, 1983), the relation between the regional allocation of public investments and the stage of economic development (e.g. Hirschman, 1958; Kamada et al., 1998 or Michel et al., 1983) or the question whether or not there is a shortage of infrastructure investment (Hulten \& Peterson, 1984; Peterson, 1990 or Tatom, 1991). This last perspective allows to judge the importance of infrastructure, nevertheless the literature gives no deep understanding of the processes directing the level of infrastructure (Ghosh \& Meagher, 2004). What are the determinants of public infrastructure investment decisions? Why the one government prefers a high level of investments while another keeps its level of public infrastructure limited? Economists will argue that the degree of public infrastructure but also changes of it- depends on inhabitants' demand. Indeed, public infrastructure will be subject to the needs of the society. Governments invest in infrastructure to provide the necessary framework for a well functioning economy. However, governments are confronted with a budget constraint. Limited resources -taxation, grants or other revenue sourcescoupled with unlimited demand for public infrastructure force governments to make decisions regarding the allocation of scarce resources. How these decisions are made? In this paper, we will investigate from a public choice approach how the level of public infrastructure investments can be explained. Theoretically, decisions on public infrastructure investment should lead to a social optimum, in practice the choice of infrastructure investments is a political process (Ghosh \& Meagher, 2004). Political economy has replaced the social planner as the organizing principle of public sector economics. Indeed, Inman (1983) shows that also infrastructure spending is a function of myopic decision making by politically motivated incumbents. Also Beetsma \& van der Ploeg (2007), Crain \& Oakley (1995) and Hulten \& Peterson (1984) point to the political constraints of public infrastructure decision making. "Public capital decisions are not made in a political vacuum" (Crain \& Oakley, 1995; 15). Therefore, we will focus on the impact of political determinants on public infrastructure investment decisions.

The impact of the choices of politicians concerning fiscal policy in general -in which public infrastructure investment decisions can be placed- has been widely studied. The Hettich \& Winer model (1984, 1988 \& 1999) assumes that the maximization of support for the government is the main objective when outlining fiscal policy. The probability of an individual voting for the governing party depends positively on the level of public services and infrastructure and negatively on the income loss of the individual due to taxation. Both 
the level of public services and infrastructure and the tax policy differ according to the partisan characteristics of the government. Theories on partisan politics attribute central importance to the ideological differences between groups within society and the parties that represent these groups (Tufte, 1978). Next to partisan influences, other theories point to politically inspired determinants of fiscal policy. The political budget cycle theory focuses on the impact of the timing of elections (Franzese, 2002). Fragmentation and interaction theories show that, respectively, the composition of the government (Ricciuti, 2004) and the fiscal policy of neighbouring jurisdictions (Besley \& Case, 1995) frame fiscal policy as well. The aim of this paper is to investigate the joint impact of various political determinants on public infrastructure investments decisions in Flemish local governments. Therefore we formulate a number of testable hypotheses concerning the factors, ceteris paribus, affecting local public infrastructure investment policy.

The remainder of this paper is structured as follows. Section 2 elucidates its focus and provides some contributions to the existing research. Section 3 reviews the literature and formulates some hypotheses. The empirical analysis is clarified in section 4, while the main findings are summarized in section 5 .

\section{Discussion}

In this paper, the focus is on an empirical test of the political determinants of public investment at the local level. This approach contributes to the literature in a number of ways.

First, our attention goes to the local government level. Studies on local public infrastructure investments are scant. Gramlich (1994) assigns this to the fact that the infrastructure problem is often undeservedly described as a problem needing federal government attention. Indeed, the literature on infrastructure is dominated by country- (and/or state-level) data as in e.g. Zelner \& Henisz (2004), Mizutani \& Tanaka (2008) or Tatom (1991). Nevertheless, research on infrastructure investments at the local level merits particular attention as Gramlich (1994) shows for U.S. public infrastructure investments. Also the figures for Belgium show that most of the public infrastructure investments is situated at the local governments. In 2006 at least $58 \%$ of the Belgian's public infrastructure creation was situated at the local level ${ }^{2}$ (Dexia, 2008). A local-level context when studying public infrastructure thus is preferred. Also from a methodological point of view, a local-level context also offers a number of advantages. Unlike studies using country data, we are able to control for institutional aspects and economic conditions as municipalities have a homogeneous institutional context. Flemish

2 This figure contains the Flemish, Walloon and Brussels local public investments. 
municipalities share common political and constitutional systems, experience common economic shocks, employ similar budgetary processes and have identical electoral rules. This allows us to concentrate on the crucial explanatory variables without having to control for other variables. Second, Flemish municipalities have a parliamentary system which makes the results of analyses comparable to studies that have tested similar models on national levels. A final advantage of a data-set at local level is related to the number of cross-sections. Municipal data allow testing models with a much larger number of observations.

Second, the literature on public infrastructure is mainly dominated by U.S. data (e.g. Bruce et al., 2007, Crain \& Oakley, 1995 or Morss et al., 1967) and is theoretical in nature. Although for different European countries the impact of politics on other fiscal policy instruments are frequently tested empirically at the local level (e.g. Allers \& Elhorst, 2005; Ashworth et al., 2005; Feld \& Kirchgassner, 2001; Geys, 2007; Leprince et al., 2007; Revelli, 2002; Solé Ollé, 2003 or Tovmo, 2007) there is no tradition in applying these insights on public infrastructure investment for such data-sets. MacManus (2004; 98) explicitly states that "identifying the politics side of capital budgeting at the local level is difficult, which explains why there have been so few analyses". ${ }^{3}$ However, some authors analysed local investments in the European area. We may refer to Fiva \& Natvik (2009), Foucault et al. (2008), Kemmerling \& Stephan (2002), Rattsø (1999), Vallés \& Zárate (2007) or Veiga \& Veiga (2007). Yet none of them focuses on the large variety of determinants that may investigate the political economy of local investments. ${ }^{4}$ This paper tries to fill this gap. We apply the different insights of the political economy literature in a single model to explain empirically public infrastructure policy at the municipal level.

3 MacManus (2004) analyses electoral results at the local level in Florida and explains the incumbents' defeats amongs others by infrastructure issues.

4 Fiva \& Natvik (2009) test if variation in incumbents' re-election probability affects public investments in Norwegian local governments. Kemmerling \& Stephan (2002) estimate the contribution of infrastructure accumulation to private production for a panel of large German cities for the non-successive years 1980, 1986 and 1988. They test in one of their estimations only some politico-economic determinants. Rattsø (1999) explicitely ignores politics when analysing the aggregate level of local investments in Norway. Vallés \& Zárate (2007) examine the possible impact of budgetary stability legislation on the capital expenditure of Spanish municipalities, but their analysis is purely financial and lacks any political determinant. Foucault et al. (2008) and Veiga \& Veiga (2007) both test some political paradigms on local public expenditures in general for French and Portuguese municipalities respectively. Their focus is not on investments, but they both extend their analyses for different kinds of expenditures, including capital expenditures. 


\section{The literature \& hypotheses}

This paper explains the level of per capita public investments in Flemish municipalities. The focus thus is on political forces. Economic forces are introduced in the analyses as control variables. This is in line with the Hettich \& Winer (1984, 1988 \& 1999) model that explains fiscal choices and fiscal policies as equilibrium outcomes of a collective choice process that is constrained by political as well as economic forces. We believe this reasoning may also hold for public investment policy -as part of fiscal policy. Also Beetsma \& van der Ploeg (2007), Bruce et al. (2007), Crain \& Oakley (1995), Ghosh \& Meagher (2004), Hulten \& Peterson (1984), Taylor (1992) and Inman (1983) recognise that public investment policy is or may be politically inspired. Hansen $(1965 ; 162)$ claims that "investment outlays result from the decisions of community authorities [whose] motives and goals play an important part in investment variability." Hettich \& Winer (2002) themselves suggest some of the fiscal policy's political determinants and e.g. refer to the role of elections, the role of governance and the structural features of revenue systems.

A large literature has examined whether the composition of the government affects fiscal policy. Mostly partisan or fragmentation characteristics have been the subjects of research, but the power of the government - mostly measured by an electoral margin variable- has also been studied. Partisan characteristics measure for the impact of ideological differences on policy outputs. Imbeau et al. (2001) overview the mainstream studies considering partisan influences on policy outcome and explicitly state that "changes in the left-right party composition of a government are hypothesized to be related to changes in policy" (Imbeau et al., 2001; 2). In fiscal policy theory, left-wing governments are believed to be more in favour of income redistribution and an active state than right-wing governments. This may lead to higher public expenditure (Hibbs, 1977 and Schmidt, 1996). We apply this insights to public infrastructure expenditures and thus expect leftist governments to have a positive effect on the level of public investments, while the opposite is true for rightist governments, which is confirmed by Bruce et al. (2007). As a result we may hypothesize that:

\section{$\underline{\mathrm{H}}_{1}$ : Leftist governments have higher levels of public infrastructure investments}

Other scholars suggest that more fragmented (or divided) governments increase public spending because several conflicting political objectives have to be accommodated. This idea originates from The Weak Government Hypothesis (Roubini \& Sachs, 1989b \& 1989a), which states that weaker -i.e. more fragmented- governments tend to follow less restrictive fiscal policies. ${ }^{5}$ Fragmentation thus leads to higher levels of expenditure, as shown in

5 For a review see Ashworth et al. (2005).

Goeminne, S. \& Smolders, C. 
Volkerink \& de Haan (2001) and Ricciuti (2004). This may also count for public infrastructure. Each government party may want to benefit specific groups with specific investments to increase electoral support. The more parties, the more investment projects will be realised. Indeed, Bruce et al. (2007) confirm their expectation that infrastructure investments are higher when the government lacks unity. Consequently we expect higher level of public investments for weaker governments. Therefore we suggest that:

\section{$\underline{\mathrm{H}}_{2}$ : More fragmented governments have higher levels of public investments}

Also the power of a government may explain tax policy. Since Frey \& Schneider (1978), it is well-established that budgetary policy is affected by the incumbents' electoral margin. The higher the electoral margin of the government, the less needs to engage in opportunistic behaviour because the government is relatively confident of re-election, regardless of its fiscal choices. When the majority is smaller, a government may want to buy the support of swing voters by additional investments in public infrastructure (Kemmerling \& Stephan, 2002). Even if these additional investments do not bring the necessary votes to stay in office, they may be beneficial for the governing party as they bind the hands of possible rival political parties that may gain office in the future (Beetsma \& van der Ploeg, 2007). Low re-election probabilities thus may also lead to an increased level of public investments. On the contrary governments with high re-election probabilities do not care much about the loss of votes due to low levels of public infrastructure as Crain \& Oakley (1995) and Mizutani \& Tanaka (2008) show. Recently Fiva \& Natvik (2009) object these general accepted expectations. They suggest that higher re-election probabilities push incumbents to invest more as they assume that incumbent policymakers consider how their decisions will influence policy in the future. The more incumbents expect to stay in office, the more they develop a long term policy and the more they invest to support this policy. ${ }^{6}$ Political stability is thus expected to cause changes in the level of investments in public infrastructure, yet the direction of its impact is a priori unknown. We therefore hypothesize that:

\section{$\underline{\mathrm{H}}_{3}$ : The level of public investments depends on the power of the government}

Since municipalities are spatially linked, governments may interact strategically when setting policies. Although there is a large literature on competition between jurisdictions when outlining tax policy ${ }^{7}$, there has been drawn little attention to this phenomenon when empirically analysing public infrastructure investments. We only know of Bruce et al. (2007),

6 Fiva \& Natvik (2009) do not succeed in confirming empirically their expectations in general. First their dataset is restricted to municipalities with at least 1000 inhabitants. Second only when they have a rightist mayor, the aggregate level of local investments is higher with higher re-election probabilities.

7 We may refer to e.g. Allers \& Elhorst (2005), Besley \& Case (1995), Brueckner \& Saavedra (2001), Goeminne (2009, Heyndels \& Vuchelen (1998), Solé Ollé (2003) and Zodrow \& Mieszkowski (1986). 
Fiva \& Natvik (2009), Foucault et al. (2008) and Taylor (1992) who empirically test intergovernmental competition on government infrastructure provision. ${ }^{8}$ The theoretic expectations are multiple. First, incumbents may be expected to mimic the policy of neighbouring governments. This is because voters are expected to use the policy of a neighbouring government as a yardstick to evaluate that of their own government when deciding whether or not to re-elect the incumbent government (Besley \& Case, 1995). Second, governments may operate as real competitors that try to attract tax base from other jurisdictions (Zodrow \& Mieszkowski, 1986), especially in a decentralised public sector where local governments received over the past 30 years competencies that go along with investments in public sector infrastructure. Investments can thereby be seen as a strategic tool in the hands of local politicians for attracting corporate activities and households. Competition between municipalities then may lead to a growth in public infrastructure as they may attempt to increase the attractiveness of the municipality to inhabitants or companies of other municipalities. Within such a competition, governments may engage in a race-to-the top whereby jurisdictions end up providing infrastructure levels well beyond those required to satisfy its population (Dembour \& Wauthy, 2009). A third reaction of neighbouring municipalities is the result of the existence of positive spillovers. In that case, benefits derived from infrastructure supplied by a neighbouring municipality may spill over onto the own municipality and may reduce the latter municipality's infrastructure investments. Given these three expectations, we may suggest that the public investments may be influenced by those neighbouring jurisdictions, so we hypothesize that:

\section{$\underline{\mathrm{H}}_{4}$ : The level of public investments interacts with that of neighbouring municipalities}

Whether or not governments change their policy at elections is the central focus of electoral cycle models. To name some, Bizer \& Durlauf (1990), Poterba (1994) and Tufte (1978) provide evidence that politicians manipulate fiscal policy for electoral purposes. They support the idea that increasing expenditures -but also lowering taxes or raising grants- before elections raises the government's chances of re-election. MacManus (2004) shows that more than the level of public services, the level of infrastructure is an important issue for local elections." She states that "for too long, [...] scholars have assumed that taxes and services are the Achilles heel for local elected officials [...]. Infrastructure related [...] issues are now more likely to result in an incumbent's defeat than taxes and services [...]". This idea is confirmed by Veiga \& Veiga (2007) as they find evidence of a political budget cycle that is

8 Although Frederiksson et al. (2004) state that there is a considerable amount of horizontal strategic interaction amongst governments when determining "infrastructure spending", their dataset contains only "total general expenditures", thus without detailed data on infrastructure spending.

9 MacManus (2004) analyzes municipal election data from 47 Florida cities where incumbents lost in 2001 and shows that infrastructure issues are important when explaining the incumbent's defeat.. Infrastructure issues are decisive for $80.0 \%$ of the defeats, while that is only $16.7 \%$ in the case of public services. 
stronger for investment than for total expenditures. Therefore we may search for the existence of political budget cycles especially in public investment policy. The theoretical expectation is that higher public investments increase the popularity of the government. We therefore test hypothesis 5 :

\section{$\underline{\mathrm{H}}_{5}$ : Public investments increase when elections are near}

\section{Empirical analysis}

To empirically test the hypotheses formulated in the previous section, we use a dataset of 307 (out of 308) Flemish municipalities for the period 1996-2006. ${ }^{10}$ In this section, we first discuss a number of characteristics of Flemish local governments and of investments in public infrastructure at the local level. Then, we provide a detailed account of the model's specification and the measurement of our variables. The methodology is clarified and, lastly, we present the empirical results

\subsection{Flemish municipalities}

Before turning to the analyses, we familiarize the unacquainted reader with some of the financial and institutional characteristics of Flemish municipalities. Of 589 Belgian municipalities, 308 are under the supervision of the Flemish Region. The governments of these municipalities have wide-ranging budgetary and fiscal autonomy. They are authorized to decide independently on the level and the structure of expenditures and revenues. Taxation generates about half of the Flemish municipalities' revenues. As in most decentralised countries, local governments in Flanders depend on higher levels of government for their revenue. Grants from higher governments (which are for the most part unconditional) are almost equal in importance to taxation in local governments' revenues. Grant revenue is important for financing investments in public infrastructure, the focus of our paper. The decision to invest has to be approved by the local Council. The Council represents the legislative body in a parliamentary system with the College of Mayor and Alderman operating as the executive body. Seats in the Council are allocated using a system of proportional representation. The College is elected -elections are held every 6 years, without term limitations- from the members of the Council. Its composition is determined by the party (or parties) holding a majority position in the Council. The number of parties in the majority differ between 1 and 5 as shown in Table A1 in appendix.

\footnotetext{
10 Voeren is removed from the dataset, as will be expounded in footnote 15.
} 


\subsection{Local public infrastructure}

We are aware that many possible definitions of "public infrastructure" exist. As in most studies on this subject (see Gramlich, 1994) we define public infrastructure as the tangible capital stock owned by the public sector. The focus in this study is on the local level as the national accounts show that local governments are the principal Belgian public sector investors. In 2006 local governments contributed for 56,8\% to the gross creation of new public capital. Their investments represent $0,7 \%$ of Belgian's GNP and amount in absolute quantities to 2.292,5 millions euro. Most of the investments at the local level, about 1.468 millions euro, are done by Flemish municipalities (Dexia, 2009). Over the period under study, Flemish local governments yearly invested on average about 200 euro per capita (see Table A3 in appendix). This amount increased from on average 139 euro per capita in 1996 till 228 euro in 2006. Flemish local governments spent in 2006 especially on road construction $(22,7 \%)$. Next, investments in economics $(20,9 \%)$ and in culture $(17,0 \%)$ are of second and third importance. Also public cleansing and urban development (15,2\%), public administration $(8,8 \%)$ and education $(3,3 \%)$ are of significant importance, while security, worship and healthcare each represent only fractions of the Flemish local governments' public infrastructure budgets (Dexia, 2008). ${ }^{11}$ These figures are derived from the "capital budget" of local governments' annual accounts. Although at the federal level the distinction between current and capital budgets dissolved, this is not the case at the municipal level where both a current budget and a capital budget are still en vogue (Vanneste, 2002). When local governments invest in public infrastructure, they have various financing opportunities. In 2006 Flemish local governments financed on average $41,8 \%$ of their investments through own resources. Therefore they used their accumulated monetary reserves and profits or they transfer funds from the current budget to the capital budget. 36,5\% of the capital budget funding derives from debt. Even though they can arrange public loans, local governments almost exclusively borrow from banks. Four fifths of local debt is contracted at the long-term to finance investments. Other opportunities to finance investments are through disinvestments $(11,9 \%)$-these are the financial resources that are available from selling infrastructure- and through grants $(9,8 \%)$ (Dexia, 2008). These grants come almost exclusively from the Flemish government.

11 Investments in security and healthcare thus are of less importance in Flemish local governments' capital budgets. This is because security and healthcare are the responsability of the local police forces and of the public centres for social welfare respectively that operate as inter- or intra-local government authorities with their own bookkeeping. The Belgian local police is made up of 196 police forces. Most of them cover the territory of more than one municipality. Police forces fund their functioning and investments with the contributions they receive from the federal government and from the local governments that are part of the zone. The contribution of the local governments comes from their current budget. Also the centres for social welfare are subsidized from the local governments' current budgets besides the grants they receive from higher levels of government. 


\subsection{Empirical model}

We develop an explanatory model for a Flemish municipality's public infrastructure investments that allows testing our hypotheses (subscripts $i$ and $t$ referring to municipalities and time respectively):

$$
\begin{aligned}
\text { INVEST }_{i t}= & \alpha_{1}+\alpha_{2} \text { ICG }_{i t}+\alpha_{3} \text { ICG }_{i t} * \text { POP }_{i t}+\alpha_{4} \text { TWOPAR }_{i t}+\alpha_{5} \text { LARGEPAR }_{\mathrm{it}} \\
& +\alpha_{6} \text { SEATMAR }_{\mathrm{it}}+\alpha_{7} \text { INVESTNEIGH }_{\mathrm{it}}+\alpha_{8} \text { ELECT }_{\mathrm{it}-5}+\alpha_{9} \text { ELECT }_{\mathrm{it}-4} \\
& +\alpha_{10} \text { ELECT }_{\mathrm{it}-3}+\alpha_{11} \text { ELECT }_{\mathrm{it}-2}+\alpha_{12} \text { ELECT }_{\mathrm{it}-1}+\alpha_{13} \text { SOCIO-ECON }_{\mathrm{it}} \\
& +\alpha_{14} \text { RESOURCES }_{\mathrm{it}}+\mathrm{u}_{\mathrm{it}}
\end{aligned}
$$

In this regression investment in public infrastructure will be declared by a number of political and socio-economic and financial determinants.

Our dependent variable INVEST represents the per capita investments in public infrastructure. This data is taken from the municipalities' capital budget and should be considered as the investment in the aggregate public infrastructure.

To test bypothesis 1, that is the impact of partisan characteristics on the level of public infrastructure investments, we introduce the Ideological Complexion of the Government (ICG) index as developed by Kontopoulos \& Perotti (1999) and used previously in research on Flemish municipalities by Ashworth et al. (2006), Geys (2007) and Goeminne (2009). ICG positions the government on a left-right scale with 0 representing extreme left and 10 representing extreme right. ICG is a weighted average of the ideological scores of the individual government parties (as shown in Table A2 on p. 21), where the weight is the relative number of mayor and/or aldermen of a certain party in the government. We hypothesized that leftist governments are more in favour of a large public sector, so the expected value of ICG is negative. As it seems likely that the partisan effect on the level of public infrastructure investments may be conditional upon the size of the municipality ${ }^{12}$, we also introduce the interaction variable ICG*POP. ${ }^{13}$

\footnotetext{
12 Flemish largest cities have a tradition of leftist governments (e.g. Antwerp, Ghent, Leuven and Oostende have socialist Mayors) in the the period under study, while small municipalities are more governed by centre governments, specifically by single party christian-democrat governments.

13 POP is measured as the municipality's number of inhabitants.
} 
Hypothesis 2 stated that fragmented governments are expected to have higher levels of infrastructure investments. Following Ashworth et al. (2005), de Haan \& Sturm (1994 \& 1997), Edin \& Ohlsson (1991), Goeminne et al. (2008) and Volkerink (2001) we test the fragmentation hypothesis by splitting the municipalities into groups. For each group a separate dummy variable is created. Dummy variables TWOPAR it and LARGEPAR it for governments consisting of, respectively, two and at least three parties -with single party governments as the remaining category-are introduced. Assuming that increases in coalition size lead to increased investments in public infrastructure, we expect the coefficient on both variables to be significantly positive. We also expect a higher coefficient large coalitions (LARGEPAR), or thus $0<\alpha_{4}<\alpha_{5 .}{ }^{14}$

The seats margin (SEATMAR) measures the strength of the government. As in Goeminne (2009) and Solé Ollé (2003) this variable is computed as the difference between the percentage of the seats of the government parties in the Council and 50\%. Hypothesis 3 predicts that public investments depend on SEATMAR. Its sign is a priori undetermined.

INVESTNEIGH is a spatial interaction variable that is added to the model to measure the impact of spatial interactions on the level public infrastructure investments and thus to test bypothesis 4. INVESTNEIGH is calculated as the average levels of public infrastructure investments of neighbouring jurisdictions. ${ }^{15}$ Like Bruce et al. (2007) we restrict the jurisdictions which are in competition with each other to geographically contiguous jurisdictions. ${ }^{16}$ As in the literature average values are used to measure for the existence of mimicking and competition behaviour, it will be impracticable to distinguish between the

14 In preliminary analyses (not shown) we also experimented with variables that measure fragmentation as a simple count of the number of parties in the ruling coalition (NPAR) and its squared form. The use of dummy variables outperformed this alternative measurement. Hence, $\mathrm{NPAR}^{(2)}$ was not retained in the final estimations.

15 We calculate unweighted averages. This approach is similar to Heyndels \& Vuchelen (1998), Van Parys \& Verbeke (2007) and Goeminne (2009) who use the unweighted average tax rates of neighbouring municipalities when testing spatial interaction in local tax rate policy. Also Foucault et al. (2008) suggest this method, but are forced to use the Euclidean distance between jurisdictions because the jurisdictions of their dataset -that is restricted to 90 municipalities with at least 50.000 inhabitants- do not necessarely share a border.

16 For Flemish municipalities across the language boundary, only Flemish neighbours are taken into account. Therefore, Voeren - that has no Flemish neighbours- is removed from the dataset. 
mimic and competition effect should the coefficient of INVESTNEIGH be positive. ${ }^{17}$ If the coefficient is negative, there is evidence of spill-over effects. ${ }^{18}$

Whether or not the time to next elections has an impact on local public investment decisions is the subject of bypothesis 5. We use a vector of dummies for each non-election year in the electoral cycle : ELECT-1, for the year before elections, till ELECT-5 for the year directly following election years - with the election year as the remaining category. ${ }^{19}$ Unlike the model of Veiga \& Veiga (2007) and Foucault et al. (2008), a vector of dummies for all non-election years allows to set out the evolution of infrastructure investments over the legislature in its entirety. ${ }^{20}$ For our purpose, the idea is that local politicians increase public investments before elections to increase their chances of re-election, while the level of investments is expected to drop once elections took place. We thus expect $\alpha_{8}<\alpha_{9}<\alpha_{10}<\alpha_{11}<\alpha_{12}$.

Next to these determinants we adopt SOCIO-ECON and RESOURCE, two vectors of control variables that may, in addition to the political variables, also influence local infrastructure investments.

SOCIO-ECON is a vector of socio-economic and demographic variables. These variables control for intermunicipal differences in preferences for local public infrastructure. Indeed, investment in infrastructure may be the result of reactions to the economic and demographic conditions (Hulten \& Peterson, 1984 and Bruce et al., 2007). These conditions may capture the public's demand for public infrastructure provision. We introduce the size of the municipality $(\mathrm{POP})^{21}$, the density of companies (COMP) ${ }^{22}$ and the tax base yield (TBASE) ${ }^{23}$

17 Brueckner (2003) shows that for the case of tax competition and tax mimicking the reaction functions to test each interaction model separately have the same form, so that it is extremely difficult (if not impossible) to empirically verify which model is appropriate.

18 Remark that no lags were introduced for the interaction variables because municipalities do not have to wait a year to observe the investments of neighbouring municipalities The decision-making of investments provokes a lot of public discussion. Council meetings -where these investment decisions are discussed- are open to the public and politicians from neighbouring municipalities often meet so they are likely to be aware of investment intentions in neighbouring municipalities and thus can react immediately. A similar assumption is made for fiscal policy research in Flemish municipalities in Geys (2006), Goeminne (2009) and Werck et al. (2008), but also in Buettner (2001) for German local governments.

19 This approach is similar to Geys (2007) when investigating debt in Flemish municipalities.

20 Veiga \& Veiga (2007) introduce only one dummy variable for election years. Foucault et al. (2008) use dummies for the election year (every six years), the year before and the year after elections.

21 POP is measured as the number of inhabitants.

22 COMP is calculated as the number of companies per capita.

23 TBASE is measured as the average of the tax revenue per capita of one percent local income tax and the tax revenue per capita of one percent (this equals 100 centimes) local property tax. This calculation is well known as "objectief belastingvermogen" in Flemish local tax policy research and is prefered to the average taxable income per capita as it also takes into account the hypothetical income that derives from one's property. This is not unimportant for our research as with respect to the property tax, next to households, also companies -that also feed the demand for public infrastructure- are subject to the property tax (about 40 percent of property tax revenues comes from companies). 
to reflect demand for "general" public infrastructure, such as public safety, streets, sewer facilities, equipment used in governmental and judicial administration,... POP and COMP are introduced as infrastructure investment may be a response to increased demand from population growth and to private sector pressure (Bruce et al., 2007; Faguet, 2002 and Kemmerling \& Stephan, 2002). The introduction of the tax base yield comes from the idea that the demand for public goods and services increases with income (Bruce et al., 2007; Costa-i-Font et al., 2003; Hulten \& Peterson, 1984 and Vallés \& Zárate, 2007). For POP, COMP and TBASE positive signs are expected. The same expectations may be pronounced for the share of young (YOUNG) ${ }^{24}$ and old people (OLD) ${ }^{25}$ and the rate of unemployment (UNEMPL) ${ }^{26}$. These variables may reflect the needs for specific public services such as education infrastructure, social housing, geriatric care,.... COAST is a dummy variable that takes the value 1 if the municipality is located at the seaside. As in Bastiaens et al. (2001) this dummy is introduced as coastal municipalities may have a different pattern of expenditures because of their tourist function. When studying the yearly investments in public infrastructure, we should also take into account the level of infrastructure already in place in a municipality. Indeed, a municipality's existing level of public infrastructure may determine the level of marginal return available from the additional investments and thus may influence the decision on these additional investments (Henisz, 2002). We add INFRA to the model. This variable represents the per capita stock of public infrastructure as presented in the municipalities' balance sheets. We expect a negative coefficient as the marginal return decreases when the stock of public infrastructure becomes larger.

RESOURCE is a vector of variables controlling for the availability of resources to the municipalities to provide public infrastructure. Indeed, Válles \& Zárate (2007) conclude that the level of public infrastructure investments is strongly dependent on the available financial resources. $^{27}$ There are several resources associated with infrastructure for Flemish municipalities. Most important resources are the grants the municipalities receive from higher governments covering for spillover effects. As mentioned before, the benefits from public infrastructure may spill over to users outside the municipality that pays for it. This may lead to an underprovision of public infrastructure (Peterson, 1990). Governments may avoid this by financing public infrastructure (partly) by intergovernmental grants, as is the case in Flemish municipalities. Therefore we introduce GRANT, the local government's per capita earmarked grant revenue for financing public infrastructure. This grant revenue compensates for the share of system costs imposed by non-residents. Nevertheless we should be aware

\footnotetext{
YOUNG is calculated as the percentage of inhabitants that are below 20.

OLD is calculated as the percentage of inhabitants that are over 64.

UNEMPL is the percentage of inhabitants that are unemployed.

27 The financial data in Veiga \& Veiga (2007) is restricted to a grant variable. Foucault et al. (2008) have no financial control variables at all. Both papers do not take into account the available stock of infrastructure.
} 
that grants may be a powerful incentive to invest in infrastructure and thus may be stimulative for local public infrastructure investment (Hulten \& Peterson, 1984 and Vallés \& Zárate, 2007). This is the case if the coefficient exceeds the value 1 . Then investments increase more than the amount of grants a municipality receives. If the coefficient is between 0 and 1, grants are substitutive or investments do not increase as much as the level of grants received. If the coefficient would be negative, then grant aid is dilutive. In that case grant revenue lowers the level of investments (Hu \& Booms, 1971). Next to grants, municipalities finance their infrastructure investments mainly through borrowing and disinvestments. We also control for these resource availabilities by introducing DEBT and DISINVEST. The use of debt is theoretically justified on the grounds of intergenerational equity. Whether or not a municipality finances its public infrastructure through borrowing may depend firstly on the municipality's ability to issue more debt (Vallés \& Zárate, 2007). Since this is related to the local government's indebtedness, we introduce DEBT. ${ }^{28}$ We expect that municipalities wishing to increase public investments are indirectly obliged to contract a higher volume of debt, so we expect this variable to be positive. Disinvestments (DISINVEST) ${ }^{29}$ may clear money for new investments. We expect it to present a positive sign. Finally, the accumulated profit (PROFIT) ${ }^{30}$ or the municipality's accumulated monetary reserves (RESERVES) ${ }^{31}$ may also be used to finance investments in public infrastructure. Again positive coefficients are expected. Here the idea is that the larger the profit or reserves, the less is the pressure to hold down public infrastructure investments (Morss et al., 1967).

Replacing SOCIO-ECON and RESOURCE in the previous equation with these control variables, we estimate the following equation:

$$
\begin{aligned}
& \text { INVEST }_{\text {it }}=\alpha_{1}+\alpha_{2} \text { ICG }_{\text {it }}+\alpha_{3} \text { ICG }_{\text {it }} * \text { POP }_{\text {it }}+\alpha_{4} \text { TWOPAR }_{\text {it }}+\alpha_{5} \text { LARGEPAR }_{\text {it }} \\
& +\alpha_{6} \text { SEATMAR }_{\mathrm{it}}+\alpha_{7} \text { INVESTNEIGH }_{\mathrm{it}}+\alpha_{8} \text { ELECT }_{\mathrm{it}-5}+\alpha_{9} \text { ELECT }_{\mathrm{it}-4} \\
& +\alpha_{10} \text { ELECT }_{\mathrm{it}-3}+\alpha_{11} \text { ELECT }_{\mathrm{it}-2}+\alpha_{12} \text { ELECT }_{\mathrm{it}-1}+\alpha_{13} \text { POP }_{\mathrm{it}}+\alpha_{14} \text { COMP }_{\mathrm{it}} \\
& +\alpha_{15} \text { TBASE }_{i t}+\alpha_{16} \text { YOUNG }_{i t}+\alpha_{17} \text { OLD }_{i t}+\alpha_{18} \text { UNEMPL }_{i t}+\alpha_{19} \text { COAST } \\
& +\alpha_{20} \text { INFRA }_{\text {it }}+\alpha_{21} \text { GRANT }_{\text {it }}+\alpha_{22} \text { DEBT }_{\text {it }}+\alpha_{23} \text { DISINVEST }_{\text {it }} \\
& +\alpha_{24} \text { PROFIT }_{\text {it- } 1}+\alpha_{25} \text { RESERVES }_{\text {it- } 1}+u_{i t}
\end{aligned}
$$

28 DEBT is the per capita long term debts in $€ 1000$.

29 DESINVEST is the per capita desinvestments as mentioned on the capital budget. These are revenues from selling public infrastructure such as buildings, rolling stock, computer equipment,... . Within the capital budget these resources can be used to finance new infrastructure.

30 PROFIT is the per capita accumulated profit of the preceding year.

31 RESERVE are the per capita monetary reserves available for redistribution in the preceding year. 
Table A3 in appendix on p. 22 shows descriptive statistics concerning both the dependent and the explanatory variables.

\subsection{Methodology}

We construct a panel data model (1996-2006) that regresses INVEST on various local characteristics that, according to the theoretical expectations, may influence the level of local public infrastructure investments. Some of these characteristics open up a discussion concerning some challenging econometric issues.

First we are confronted with a "between municipalities" simultaneity problem. To measure for the impact of competition, neighbours' investment levels are introduced in the regression. These levels are supposed to be endogenous. The level of infrastructure investments in municipality i depends on that in municipality j, but also vice versa. This introduces a specific simultaneity problem, which is well established in the spatial econometrics literature (Cliff \& Ord, 1973). In general the presence of endogenous regressors at the right-hand side of the equation leads to biased OLS estimates. Also Besley \& Case (1995), Heyndels \& Vuchelen (1998), Brett \& Pinkse (2000), Buettner (2001), Solé Ollé (2003) and Goeminne (2009) are confronted with this problem when investigating the impact of competition on fiscal policy. Like them we adopt an instrumental variables (IV) approach that controls for additional spatial auto-correlation of residuals, as demonstrated by Kelejian \& Pruncha (1998). We introduce the neighbouring municipality's average tax base yield, its population size, its percentages of people under 20 and over 64 years and its average level of investments over the past 3 years as instruments in the model. The Sargan tests on the validity of the instruments indicate that the instruments are valid. ${ }^{32}$

\subsection{Results}

Table 1 presents the results of the investment estimation. A two stages least squares (2SLS) regression on panel data with random effects is implemented and covers data from 307 of the 308 Flemish municipalities. ${ }^{33}$ Since our number of years is small comparing to the number of cross-sectional units, random effects model estimators are more efficient than fixed effects model estimators (Gujarati, 2003; 651). Moreover, introducing a fixed effects model would be

32 The Sargan test tests the validity of the instrumental variables. Under the null hypothesis that all instruments are valid -they are uncorrelated to some set of residuals- the Sargan statistic is Chi ${ }^{2}$ distributed with $\mathrm{R}$ degrees of freedom ( $\mathrm{R}$ being the number of instruments minus the number of estimated parameters). If we fail to reject the hypothesis -which is the case in our model, since p exceeds the value 0.10 - the instruments are acceptable.

33 Voeren - a municipality without Flemish neighbours- is removed from the dataset to allow testing interaction effects. See footnote 16. 
expensive in terms of degrees of freedom. The Hausman tests also suggest that it is safe to use random effects. ${ }^{34} \mathrm{~A}$ correlation analysis showed that our dataset does not lack from multicollinearity. ${ }^{35}$ Finally, Wald tests were performed and reject the null hypotheses that all slope coefficients of our analysis are equal to zero.

We present different regression results in Table 1. The most general estimation in column (1) includes all the available explanatory variables. We then stepwise eliminate the least significant variables until we obtain a model with only statistically significant -at least at the $10 \%$ level- coefficients in column (2). In general, results match well with the predicted political effects. Our model explains about $39 \%$ of the variance of INVEST. The adjusted $\mathrm{R}^{2}$ gives no indication that regressors are added without contributing to the explanatory power of the model.

34 A Hausman test controls whether the $\mathrm{H}_{0}$ that the coefficients estimated by the random effects estimator are the same as the ones estimated by the fixed effects estimator. The insignificant p-values presented in our model indicate that we fail to reject the $\mathrm{H}_{0}$ and allows us to use random effects.

35 The correlation matrix (not shown) indicated that, except for the interaction term ICG*POP with its component part POP, none of the pairwise correlation coefficients exceed the suggested threshold of $|\mathrm{r}|>0.80$ (see Gujarati, 2003; 359). Brambor et al. (2006) show that high levels of collinearity are not problematic for interaction analysis. 
Table 1 Estimation results of the 2SLS estimation

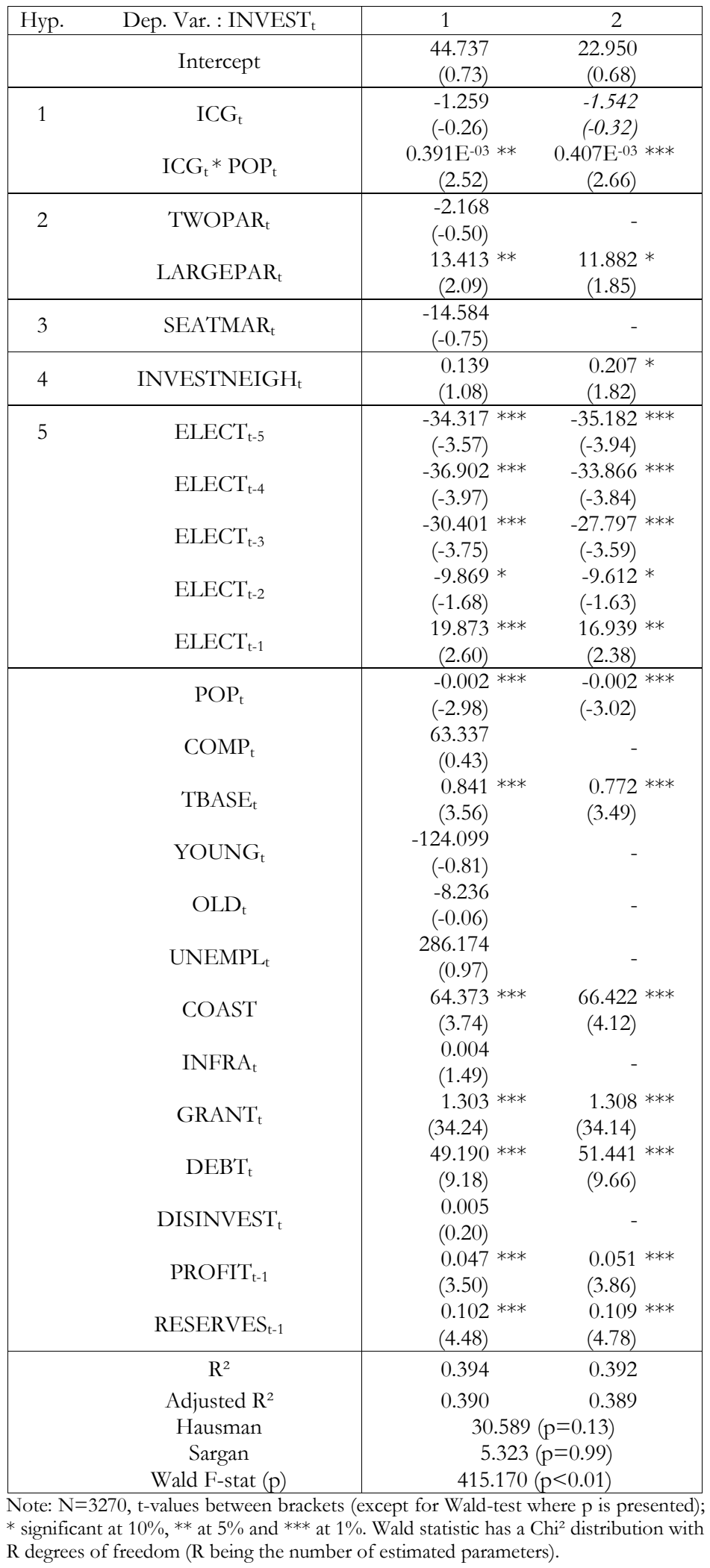

The key finding of Table 1 is that our variables of interest, i.e. the political variables, present statistically significant effects on the level of public infrastructure investment. We discuss the results hypothesis by hypothesis. 
For bypothesis 1 on partisan politics, we find in line with Bruce et al. (2007) that rightist governments have a preference for lower public investments. Nevertheless the effect is not significant. ${ }^{36}$ This corresponds to Veiga \& Veiga (2007) and Foucault et al. (2008). Still the interaction effect ICG * POP presents a significant coefficient. We hypothesized that the effect of the partisan politics on the level of infrastructure investments may be moderated by the size of the municipality. The significant coefficient of ICG * POP suggest that this is the case. This coefficient indicates how the relationship between the level of public infrastructure investment and the partisan characteristics of the government varies across the size of the municipality. For every 1000 inhabitants, the slope of public infrastructure investment on the value of ICG is predicted to increase with 0.407 units.

Considering bypothesis 2 on fragmentation Table 1 shows that fragmentation affects the level of public infrastructure investments in Flemish municipalities. Especially governments with at least three coalition members have significantly higher levels of public infrastructure investments. There is no evidence that two-party-governments invest significantly more than single party governments.

With respect to bypothesis 3 in line with the early literature the sign of SEATMAR is negative, yet the coefficient remains insignificant, so we may conclude that for Flemish municipalities there is no significant impact of the seats margin on the level of public infrastructure investments.

Hypothesis 4 was related to the impact of neighbouring municipalities' investment decisions. As in Foucault et al. (2008) we find evidence that the level of public infrastructure investments depends on that of neighbouring municipalities. The coefficient of 0.207 indicates that governments whose neighbours increase their investments by 1.000 euro per capita will also increase their investments by 207 euro per capita. As mentioned before, a positive coefficient does not allow distinguishing between a possible mimicking or competition effect.

There is strong evidence that confirms bypothesis 5 . In line with the expectations, we find that governments change the level of investments depending on the time to next elections. The electoral cycle variables present evidence that investments maximize in the year before elections. The lowest level of investments can be assessed in the year after elections. It's clear that incumbents increase the level of public infrastructure investments when elections come

36 When an interaction term is significant, the constitutive variables of the interaction model remain included regardless of whether they are significant. Therefore ICG is presented in the efficient regression. As the coefficient is insignificant, it is shown in italic. 
closer. They thus may expect that higher public investments increase their popularity. The highest level of public infrastructure investments is not recorded in election years, but in the year before elections. This can be explained by the completion time of public investments. It's not uncommon that public investments have a construction period of more than a year think of the building of a new sports centre, the renovation of the marketplace,...- so inhabitants may benefit from the investments started in the pre-electoral year for the first time in the year they have to go to the voting booth.

Finally, some general findings on the control variables. Several of them have consistent effects on public infrastructure investments. Three variables were introduced to capture the public's demand for general public infrastructure provision. The tax base yield (TBASE) has the expected positive effect on public infrastructure provision. As in Kemmerling \& Stephan (2002) the presence of companies (COMP) does not affect the level of investments. Opposite to the expectations, the size of the municipality (POP) presents a negative sign, so smaller municipalities invest more per capita than larger municipalities. We can think of different explanations for this divergent sign. First, as Morss et al. (1967) suggest, in the short run, population pressures may affect current expenditures in the expected positive direction, but not capital expenditures. Second, large municipalities have more access to large infrastructure projects financed by the federal or regional government, so some of the investment needs are financed by a higher government. Finally, Flemish smaller municipalities engaged a strategy to restrict townwards migration leading to a process of suburbanisation and urbanisation of small municipalities. Increasing public infrastructure may attract inhabitants or companies to move from larger cities to smaller municipalities or may prevent them of moving from the municipality to larger cities. In fact this is in line with the competition hypothesis we have confirmed above. Except for COAST, none of the variables that may reflect the needs for specific public services explains the level of public infrastructure investments. ${ }^{37}$ An explanation could be that we only analyse total public infrastructure investments. The tourist function seems to impose coastal municipalities (COAST) to increase investments in public infrastructure with on average 66,42 euro per capita. Another explanation could be that coastal municipalities benefit from tax export and thus have more resources to finance public investments. ${ }^{38}$ In line with Vallés \& Zárate (2007) we may conclude that the level of public infrastructure investments is strongly dependent on the available sources of finance. GRANT, DEBT, PROFIT and RESERVES present the expected positive sign. The more

37 To capture a possible lag between the presence of the needs and the reaction of local governments to these needs, we experimented with lagged values (up to 5 years) of these control variables. Still this does not change the results fundamentally.

38 Bastiaens et al. (2001) show that Flemish coastal municipalities have on average higher expenditures without the need to impose higher tax rates. Their explanation is that coastal municipalities can shift taxes to non-residents via the second home tax an the property tax on these residences. 
debt, the higher the accumulated profit and the stronger the reserves of a municipality, the higher are the investments in public infrastructure. Unlike Kemmerling \& Stephan (2002) we find a significant impact of the level of grants on public infrastructure investments. Our results show moreover that the coefficient of GRANT is larger than 1, suggesting a positive flypaper effect or thus that grants are stimulative for local public infrastructure investment. For each 1000 euro grants local governments receive to finance public infrastructure, they finally invest 1308 euro.

\section{Conclusion}

In this paper, we estimated a public infrastructure investment function using a panel data set of 307 Flemish municipalities for the period 1996-2006. Attention is particularly drawn to political determinants of public infrastructure investment decisions. Although the literature indicates that identifying the political determinants of capital budgeting is difficult especially at the local level (MacManus, 2004), our empirical model succeeds in appointing political powers that significantly affect the level of public infrastructure investments in Flemish municipalities. The characteristics of the government affect the level of public infrastructure investments as we show that the partisan features, when interacted with the size of the municipality, as well as the fragmentation of the College direct public infrastructure investments. We show that coalitions with at least three members invest more than single or two party governments. Local governments are also sensitive to the investment policy of neighbouring municipalities. There is a positive interaction effect that changes own investments by $20 \%$ of that of neighbouring municipalities. Finally, elections obviously have an impact on investment policy. Investments increase the nearer elections come. Still, highest investments cannot be viewed in election years, but in the year before elections what could be explained by the completion period of infrastructural investments. In line with Vallés \& Zárate (2007) our results indicate that municipalities are strongly dependent on the availability of resources to provide public infrastructure. Nevertheless, our regression shows that local public investment policy is strongly dependent on politics. 


\section{Appendices}

Table A1 Size of the College of Mayor and Alderman in Flanders $(\mathrm{N}=308)$

\begin{tabular}{|ccc|}
\hline & $1995-2000$ & $2001-2006$ \\
\hline 1 party & 121 & 96 \\
2 parties & 148 & 163 \\
3 parties & 31 & 41 \\
4 parties & 7 & 8 \\
5 parties & 1 & 0 \\
\hline Average number of parties & 1.76 & 1.87 \\
\hline
\end{tabular}

Source : own calculations on MICE, VUB

Table A2 Ideological positions of Flemish parties

\begin{tabular}{|lcc|}
\hline General name & 1995-2000 & 2001-2006 \\
\hline Ecologists & 2.6 & 2.6 \\
Socialists & 2.7 & 2.8 \\
Nationalists & 4.7 & 5.0 \\
Christian Democrats & 5.3 & 5.3 \\
Liberals & 6.1 & 6.0 \\
Extreme right & 8.9 & 8.7 \\
\hline
\end{tabular}

Source : Rihoux (2001) 
Table A3 Descriptive statistics of the variables of the investment decision function and data sources (1996-2006, n=3270)

\begin{tabular}{|c|c|c|c|c|c|c|}
\hline & Mean & Median & Max. & Min. & Std. Dev. & Source \\
\hline $\begin{array}{l}\text { Investments in public infrastructure per capita } \\
\text { (INVEST } T_{t} \text { ) }\end{array}$ & 200.45 & 168.45 & 1474.21 & 0.79 & 133.60 & Dexia $^{39} ;$ AHA $^{40}$ \\
\hline Ideological Complexion Of the Government $\left(\mathrm{ICG}_{\mathrm{t}}\right)$ & 4.93 & 5.10 & 6.10 & 2.70 & 0.56 & MICE, VUB 41 \\
\hline Government with two parties $\left(\mathrm{TWOPAR}_{\mathrm{t}}\right)$ & 0.51 & 1.00 & 1.00 & 0.00 & 0.50 & MICE, VUB \\
\hline $\begin{array}{l}\text { Government with at least three parties } \\
\left(\text { LARGEPAR }_{\mathrm{t}}\right)\end{array}$ & 0.12 & 0.00 & 1.00 & 0.00 & 0.32 & MICE, VUB \\
\hline Seats margin $\left(\right.$ SEATMAR $\left._{\mathrm{t}}\right)$ & 0.13 & 0.10 & 0.50 & 0.00 & 0.11 & MICE, VUB \\
\hline $\begin{array}{l}\text { Average public infrastructure investments in } \\
\text { neighbouring municipalities (INVESTNEIGH }{ }_{t} \text { ) }\end{array}$ & 201.18 & 190.11 & 602.61 & 37.86 & 74.12 & $\begin{array}{l}\text { Dexia; AHA; matrix } \\
\text { of MICE, VUB }\end{array}$ \\
\hline The number of inhabitants $\left(\mathrm{POP}_{\mathrm{t}}\right)$ & 19437.55 & 13587.00 & 466203.00 & 82.00 & 30876.48 & FPS Economy ${ }^{42}$ \\
\hline The number of companies per capita $\left(\mathrm{COMP}_{\mathrm{t}}\right)$ & 0.07 & 0.07 & 0.22 & 0.02 & 0.02 & FPS Economy \\
\hline Tax base yield $\left(\mathrm{TBASE}_{\mathrm{t}}\right)$ & 46.05 & 43.60 & 87.17 & 12.46 & 11.25 & FPS Economy \\
\hline Proportion of young $\left(\right.$ YOUNG $\left._{t}\right)$ & 0.23 & 0.23 & 0.31 & 0.14 & 0.02 & FPS Economy \\
\hline Proportion of elderly $\left(\mathrm{OLD}_{\mathrm{t}}\right)$ & 0.16 & 0.17 & 0.26 & 0.08 & 0.03 & FPS Economy \\
\hline Unemployment rate (UNEMPL $\left.{ }_{t}\right)$ & 0.02 & 0.02 & 0.07 & 0.00 & 0.01 & FPS Economy \\
\hline The stock of public infrastructure per capita $\left(\right.$ INFRA $\left._{t}\right)$ & 3515.43 & 3339.79 & 10987.00 & 66.82 & 1113.97 & Dexia; AHA \\
\hline $\begin{array}{l}\text { Grant revenue for financing public infrastructure per } \\
\text { capita }\left(\text { GRANT }_{t}\right)\end{array}$ & 38.05 & 24.00 & 873.31 & 0.00 & 48.17 & Dexia; AHA \\
\hline $\operatorname{Debt}(\mathrm{p} / \mathrm{c}$ in $1000 €)\left(\mathrm{DEBT}_{\mathrm{t}}\right)$ & 1.00 & 0.94 & 7.57 & 0.00 & 0.49 & $\begin{array}{l}\text { MICE, VUB; } \\
\text { Dexia; AHA }\end{array}$ \\
\hline Disinvestments per capita $\left(\right.$ DISINVEST $\left._{t}\right)$ & 26.60 & 1.91 & 1627.13 & 0.00 & 80.81 & Dexia; AHA \\
\hline $\begin{array}{l}\text { The accumulated profit of the preceding year per } \\
\text { capita }\left(\text { PROFIT }_{\mathrm{t}-1}\right)\end{array}$ & 157.45 & 134.76 & 1949.94 & -560.55 & 150.17 & Dexia; AHA \\
\hline $\begin{array}{l}\text { The accumulated monetary reserves per capita } \\
\left(\text { RESERVES }_{\mathrm{t}-1}\right)\end{array}$ & 73.48 & 34.79 & 860.87 & 0.00 & 99.96 & Dexia; AHA \\
\hline
\end{tabular}

39) Dexia Bank.

40 Agency for Home Affairs of the Flemish Government.

41 MICE (Micro-Economics for Profit and Non Profit Sector) research team of the Faculty of Economic, Social and Political Sciences, and Solvay Business School, Vrije Universiteit Brussel.

42 Belgian Federal Public Service Economy, SME, Independent Professions and Energy. 


\section{References}

Allers, M.A. \& Elhorst, J.P., 2005, Tax mimicking and yardstick competition among local governments in the Netherlands, International Tax and Public Finance 12(4), 493-513.

Aschauer, D., 1989, Is public expenditure productive?, Journal of Monetary Economics 23(2), 177200.

Ashworth, J., Geys, B. \& Heyndels, B., 2005, Government weakness and local public debt development in Flemish municipalities, International Tax and Public Finance 12(4), 395-422.

Ashworth, J., Geys, B. \& Heyndels, B., 2006, Determinants of tax innovation : the case of environmental taxes in Flemish municipalities, European Journal of Political Economy 22(1), 223-247.

Bastiaens, E., De Borger, B. \& Vanneste, J., 2001, Expenditure and taxation effects of local public debt and unconditional grants: evidence from Flemish municipalities, Cabiers économiques de Bruxelles 171, 71-89.

Beetsma, R. \& van der Ploeg, F., 2007, The political economy of public investment. Brussels: European Communicties.

Besley, T. \& Case, A., 1995, Incumbent Behavior - Vote-Seeking, Tax-Setting, and Yardstick Competition, American Economic Review 85(1), 25-45.

Bizer, D.S. \& Durlauf, S.N., 1990, Testing the Positive Theory of Government Finance, Journal of Monetary Economics 26(1), 123-141.

Brambor, T., Clark, W.R. \& Golder, M., 2006, Understanding interaction models: Improving empirical analyses, Political Analysis 14(1), 63-82.

Brett, C. \& Pinkse, J., 2000, The determinants of municipal tax rates in British Columbia, Canadian Journal of Economics-Revue Canadienne D Economique 33(3), 695-714.

Bruce, D., Carroll, D.A., Deskins, J.A. \& Rork, J.C., 2007, Road to Ruin? A Spatial Analysis of State Highway Spending, Public Budgeting \& Finance 27(4), 66-85.

Brueckner, J.K., 2003, Strategic interaction among governments: An overview of empirical studies, International Regional Science Review 26(2), 175-188.

Brueckner, J.K. \& Saavedra, L.A., 2001, Do local governments engage in strategic property-tax competition?, National Tax Journal 54(2), 203-229.

Buettner, T., 2001, Local business taxation and competition for capital: the choice of the tax rate, Regional Science and Urban Economics 31(2-3), 215-245.

Cliff, A.D. \& Ord, J.K., 1973, Spatial processes : models and applications. London: Pion.

Costa-i-Font, J., Rodriguez-Oreggia, E. \& Lunapla, D., 2003, Political competition and porkbarrel politics in the allocation of public investment in Mexico, Public Choice 116(1), 185204.

Crain, W.M. \& Oakley, L.K., 1995, The Politics of Infrastructure, The Journal of Law and Economics $38(1), 1-17$.

de Haan, J. \& Sturm, J.E., 1994, Political and institutional determinants of fiscal policy in the European Community, Public Choice 80(1), 157-172.

de Haan, J. \& Sturm, J.E., 1997, Political and economic determinants of OECD budget deficits and government expenditures: A reinvestigation, European Journal of Political Economy 13(4), 739-750.

Dembour, C. \& Wauthy, X., 2009, Investment in public infrastructure with spillovers and tax competition between contiguous regions, Regional Science and Urban Economics 39(6), 679687.

Dexia, 2008, Lokale financiën - Gemeenten \& Provincies. Brussel: Dexia Bank.

Dexia, 2009, Lokale financiën - Gemeenten \& Provincies. Brussel: Dexia Bank. 
Edin, P.A. \& Ohlsson, H., 1991, Political determinants of budget deficits: Coalition effects versus minority effects, European Economic Review 35(8), 1597-1603.

Faguet, J.-P., 2002, The Determinants of Central vs. Local Government Investment: Institutions and Politics Matter, Development Studies Institute Working Paper Series 02-38.

Feld, L.P. \& Kirchgassner, G., 2001, Income tax competition at the State and Local Level in Switzerland, Regional Science and Urban Economics 31(2-3), 181-213.

Fiva, J.H. \& Natvik, G.J., 2009, Do re-election probabilities influence public investment?, Norges Bank Working Paper 13.

Foucault, M., Madies, T. \& Paty, S., 2008, Public spending interactions and local politics. Empirical evidence from French municipalities, Public Choice 137(1), 57-80.

Franzese, R.J., 2002, Electoral and partisan cycles in economic policies and outcomes, Annual Review of Political Science 5, 369-421.

Fredriksson, P.G., List, J.A. \& Millimet, D.L., 2004, Chasing the smokestack: strategic policymaking with multiple instruments, Regional Science and Urban Economics 34(4), 387410.

Frey, B. \& Schneider, F., 1978, An empirical study of politico-economic interaction in the United States, The Review of Economics and Statistics 60, 174-183.

Geys, B., 2006, Looking across borders: A test of spatial policy interdependence using local government efficiency ratings, Journal of Urban Economics 60(3), 443-462.

Geys, B., 2007, Government weakness and electoral cycles in local public debt: Evidence from Flemish municipalities, Local Government Studies 33(2), 237-251.

Ghosh, A. \& Meagher, K., 2004, Political Economy of Infrastructure Investment: A Spatial Approach, North American Econometric Society Summer Meetings, Brown University.

Goeminne, S., 2009, Essays on strategic fiscal policy in Flemish municipalities: Steunpunt Fiscaliteit \& Begroting.

Goeminne, S., Geys, B. \& Smolders, C., 2008, Political fragmentation and projected tax revenues: evidence from Flemish municipalities, International Tax and Public Finance 15(3), 297-315.

Gramlich, E.M., 1994, Infrastructure Investment - a Review-Essay, Journal of Economic Literature 32(3), 1176-1196.

Gujarati, D.N., 2003, Basic Econometrics. New York: McGraw-Hill.

Hansen, N.M., 1965, The structure and determinants of local public investment expenditures, The Review of Economics and Statistics 47(2), 150-162.

Henisz, W.J., 2002, The institutional environment for infrastructure investment, Industrial and Corporate Change 11(2), 355-389.

Hettich, W. \& Winer, S., 1984, A Positive Model of Tax Structure, Journal of Public Economics 24(1), 67-87.

Hettich, W. \& Winer, S., 1988, Economic and political foundations of tax structure, The American Economic Review 78(4), 701-712.

Hettich, W. \& Winer, S., 1999, Democratic choice and taxation. Cambridge: Cambridge University Press.

Hettich, W. \& Winer, S., 2002, Public choices and fiscal means : analyzing taxes as collective outcomes. In D.P. Racheter \& R.E. Wagner (Eds.), Politics, taxation and the rule of law: the power to tax in constitutional perspective. Massachusetts: Kluwer Academic Publishers.

Heyndels, B. \& Vuchelen, J., 1998, Tax mimicking among Belgian municipalities, National Tax Journal 51(1), 89-101.

Hibbs, D.A., 1977, Political parties and macro-economic policy, American Political Science Review 71, 1467-1487.

Hirschman, A., 1958, The strategy of economic development. London: Yale University.

Hu, T.-W. \& Booms, B.H., 1971, A simultaneous equation model of public expenditure decisions in large cities, The Annals of Regional Science 5(2), 73-85. 
Hulten, C.R. \& Peterson, G.E., 1984, The Public Capital Stock: Needs, Trends, and Performance, American Economic Review 74(2), 166-173.

Imbeau, L.M., Petry, F. \& Lamari, M., 2001, Left-right party ideology and government policies: A meta-analysis, European Journal of Political Research 40(1), 1-29.

Inman, R., 1983, Anatomy of a fiscal crisis, Philadelphia Federal Reserve Bank Business Review(Oct./Nov.), 15-22.

Kamada, K., Okuno, N. \& Futagami, R., 1998, Decisions on regional allocation of public investment: the case of Japan, Applied Economics Letters 5(8), 503-506.

Kelejian, H.H. \& Prucha, I.R., 1998, Generalized spatial two-stage least squares procedure for estimating a spatial autoregressive model with autoregressive disturbances, Journal of Real Estate Finance and Economics 17(1), 99-121.

Kemmerling, A. \& Stephan, A., 2002, The contribution of local public infrastructure to private productivity and its political economy: evidence from a panel of large German cities, Public Choice 113(3), 403-424.

Kontopoulos, Y. \& Perotti, R., 1999, Government fragmentation and fiscal policy outcomes: Evidence from OECD countries. In J.M. Poterba \& J. Von Hagen (Eds.), Fiscal institutions and fiscal performance, 81-102. Chicago: University of Chicago Press.

Leprince, M., Madies, T. \& Paty, S., 2007, Business tax interactions among local governments: An empirical analysis of the French case, Journal of Regional Science 47(3), 603-621.

MacManus, S.A., 2004, "Bricks and Mortar" Politics: How Infrastructure Decisions Defeat Incumbents, Public Budgeting \& Finance 24(1), 96-112.

Michel, P., Pestieau, P. \& Thisse, J.F., 1983, Regional allocation of investment with distributive objectives, Journal of Regional Science 23(2), 199-209.

Mizutani, F. \& Tanaka, T., 2008, Productivity effects and determinants of public infrastructure investment, The Annals of Regional Science, Accepted for publication.

Morss, E.R., Fredland, J.E. \& Hymans, S.H., 1967, Fluctuations in state expenditures: An econometric analysis, Southern Economic Journal 33, 496-517.

Peterson, G.E., 1990, Is Public Infrastructure Undersupplied?, Ferderal Reserve Bank Of Boston Conference Series 34, 113-142.

Poterba, J.M., 1994, State Responses to Fiscal Crises - the Effects of Budgetary Institutions and Politics, Journal of Political Economy 102(4), 799-821.

Ratner, J.B., 1983, Government capital and the production function for U.S. private output, Economics Letters 13(2-3), 213-217.

Rattsø, J., 1999, Aggregate local public sector investment and shocks: Norway 1946-1990, Applied Economics 31(5), 577-584.

Revelli, F., 2002, Local taxes, national politics and spatial interactions in English district election results, European Journal of Political Economy 18, 281-299.

Ricciuti, R., 2004, Political fragmentation and fiscal outcomes, Public Choice 118(3-4), 365-388.

Rihoux, B., 2001, Iedereen naar het politieke centrum en voorstander van de Nieuwe Politieke Cultuur : de ideologische positionering van de lokale partijafdelingen in België, Tijdschrift van Dexia Bank 216, 7-18.

Roubini, N. \& Sachs, J.D., 1989a, Government spending and budget deficits in the industrial countries, Economic Policy 8, 99-132.

Roubini, N. \& Sachs, J.D., 1989b, Political and Economic-Determinants of Budget Deficits in the Industrial Democracies, European Economic Review 33(5), 903-933.

Schmidt, M.G., 1996, When parties matter: A review of the possibilities and limits of partisan influence on public policy, European Journal of Political Research 30(2), 155-183.

Solé Ollé, A., 2003, Electoral accountability and tax mimicking : the effects of electoral margins, coalition government and ideology, European Journal of Political Economy 19, 685-713.

Tatom, J., 1991, Should government spending on capital goods be raised?, Federal Reserve Bank of St. Louis Review 73(3), 3-15. 
Taylor, L., 1992, Infrastructural competition among jurisdictions, Journal of Public Economics 49(2), 241-259.

Tovmo, P., 2007, Budgetary Procedures and Deficits in Norwegian Local Governments, Economics of Governance 8(1), 37-49.

Tufte, E., 1978, Political control of the economy. Princeton: Princeton Univ. Press.

Vallés, J. \& Zárate, A., 2007, Fiscal Federalism, European Stability Pact, and Municipal Investment Finance: A Microdata Analysis of Spanish Municipalities, The Journal of Federalism 37(1), 68-102.

Van Parys, S. \& Verbeke, T., 2007, Tax competition among Belgian Municipalities: A multidimensional battle?, Spatial Econometrics Conference, Cambridge.

Vanneste, J., 2002, Local public finance in Belgium : structure, budgets and debt. In B. Dafflon (Ed.), Local public finance in Europe. Northampton: Edward Elgar Publishing.

Veiga, L.G. \& Veiga, F.J., 2007, Political business cycles at the municipal level, Public Choice 131(1), 45-64.

Volkerink, B. \& de Haan, J., 2001, Fragmented government effects on fiscal policy: New evidence, Public Choice 109(3-4), 221-242.

Werck, K., Heyndels, B. \& Geys, B., 2008, The impact of 'central places' on spatial spending patterns: evidence from Flemish local government cultural expenditures, Journal of Cultural Economics 32(1), 35-58.

Zelner, B.A. \& Henisz, W.J., 2004, Politics and Infrastructure Investment: SSRN.

Zodrow, G.R. \& Mieszkowski, P., 1986, Pigou, Tiebout, Property Taxation, and the Underprovision of Local Public-Goods, Journal of Urban Economics 19(3), 356-370. 